\title{
Co-generation of ethanol and L-lactic acid from corn stalk under a hybrid process
}

\author{
Yong Wang ${ }^{1}$, Jinlong Liu' ${ }^{1}$, Di Cai ${ }^{2}$ and Guoqun Zhao ${ }^{1 *}$
}

\begin{abstract}
Background: Corn stover, as one important lignocellulosic material, has characteristics of low price, abundant output and easy availability. Using corn stover as carbon source in the fermentation of valuable organic chemicals contributes to reducing the negative environmental problems and the cost of production. In ethanol fermentation based on the hydrolysate of corn stover, the conversion rate of fermentable sugars is at a low level because the native S. cerevisiae does not utilize xylose. In order to increase the conversion rate of fermentable sugars deriving from corn stover, an effective and energy saving biochemical process was developed in this study and the residual xylose after ethanol fermentation was further converted to L-lactic acid.

Results: In the hybrid process based on the hydrolysate of corn stover, the ethanol concentration and productivity reached $50.50 \mathrm{~g} \mathrm{~L}^{-1}$ and $1.84 \mathrm{~g} \mathrm{~L}^{-1} \mathrm{~h}^{-1}$, respectively, and the yield of ethanol was $0.46 \mathrm{~g} \mathrm{~g}^{-1}$. The following fermentation of L-lactic acid provided a product titer of $21.50 \mathrm{~g} \mathrm{~L}^{-1}$ with a productivity of $2.08 \mathrm{~g} \mathrm{~L}^{-1} \mathrm{~h}^{-1}$, and the yield of L-lactic acid was $0.76 \mathrm{~g} \mathrm{~g}^{-1}$. By adopting a blank aeration before the inoculation of B. coagulans LA1507 and reducing the final cell density, the L-lactic acid titer and yield reached $24.25 \mathrm{~g} \mathrm{~L}^{-1}$ and $0.86 \mathrm{~g} \mathrm{~g}^{-1}$, respectively, with a productivity of $1.96 \mathrm{~g} \mathrm{~L}^{-1} \mathrm{~h}^{-1}$.

Conclusions: In this work, the air pumped into the fermentor was used as both the carrier gas for single-pass gas stripping of ethanol and the oxygen provider for the aerobic growth of B. coagulans LA1507. Ethanol was effectively separated from the fermentation broth, while the residual medium containing xylose was reused for L-lactic acid production. As an energy-saving and environmental-friendly process, it introduced a potential way to produce bioproducts under the concept of biorefinery, while making full use of the hydrolysate of corn stover.
\end{abstract}

Keywords: Corn stover, Ethanol, L-Lactic acid, Co-generation, Saccharomyces cerevisiae, Bacillus coagulans

\section{Background}

In ethanol production, lignocellulosic biomass which is the most abundant raw material has been widely used [1]. Due to its projected positive attributes in terms of economic, environmental, and social sustainability, cellulosic ethanol has been widely regarded as a promising alternative liquid fuel [2]. However, the cellulosic ethanol production is extremely limited because the dominant pentose sugar in hydrolysate of lignocellulosic biomass

\footnotetext{
*Correspondence: gqzhao18@126.com

${ }^{1}$ Fermentation Engineering Technology Research Center of Heibei Province, College of Bioscience \& Bioengineering, Hebei University of Science and Technology, Shijiazhuang 050000, People's Republic of China

Full list of author information is available at the end of the article
}

can not be utilized by the native S. cerevisiae [3]. Thus, the hydrolysates obtained from lignocellulosic biomass containing xylose require an economic conversion in biorefinery process through xylose utilization.

It is a challenge to directly construct genetically engineered $S$. cerevisiae that would be able to ferment xylose in lignocellulose hydrolysates to ethanol [4]. The introduction into $S$. cerevisiae of a pathway for xylose-utilizing organism has been intensively studied [5-9]. However, due to internal limitations of engineered $S$. cerevisiae, multifarious optimization was normally required [10]: modified genes coding for enzymes in the pentose phosphate pathway [11], random mutagenesis [12] and laboratory evolution $[12,13]$ have been employed to further improve xylose-fermenting ability.

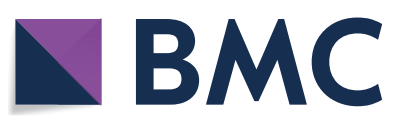

(c) The Author(s) 2018. This article is distributed under the terms of the Creative Commons Attribution 4.0 International License (http://creativecommons.org/licenses/by/4.0/), which permits unrestricted use, distribution, and reproduction in any medium, provided you give appropriate credit to the original author(s) and the source, provide a link to the Creative Commons license, and indicate if changes were made. The Creative Commons Public Domain Dedication waiver (http://creativecommons.org/ publicdomain/zero/1.0/) applies to the data made available in this article, unless otherwise stated. 
To effectively utilize xylose, the production of highvalue products such as furfural and xylitol along with ethanol fermentation based on cellulose under the biorefinery concept has been reported [14, 15]; however, a relatively small market limits the development of above products [16]. Other than a single-organism approach, a new strategy for efficient co-utilization of glucose and xylose from the hydrolysates of corn stalk was proposed in this study, and a two-stage fermentation was conducted for cogeneration of ethanol and L-lactic acid.

\section{Results}

Products accumulation and sugars utilization during ethanol and L-lactic acid fermentation

For S. cerevisiae M3013 and B. coagulans LA1507, to investigate the utilization capacity of carbon sources, batch fermentations were conducted as shown in Fig. 1. During ethanol fermentation, glucose was rapidly exhausted within $10.00 \mathrm{~h}$ and no xylose uptake was detected (Fig. 1a). The ethanol titer and productivity reached $21.45 \mathrm{~g} \mathrm{~L}^{-1}$ and $2.15 \mathrm{~g} \mathrm{~L}^{-1} \mathrm{~h}^{-1}$, respectively, and a yield of $0.47 \mathrm{~g} \mathrm{~g}^{-1}$ was obtained. The xylose metabolism defect of native S. cerevisiae has been reported by Barnett in 1976 [17], which was confirmed in S. cerevisiae M3013. Profiles of sugars utilization and L-lactic acid production by B. coagulans LA1507 Are illustrated in Fig. 1b. In aerobic stage, a cell density $\left(\mathrm{OD}_{620}\right)$ of 15.90 was eventually obtained, and $10.00 \mathrm{~g} \mathrm{~L}^{-1}$ xylose was totally consumed within $5.00 \mathrm{~h}$. No accumulation was observed in aerobic stage, indicating that L-lactic acid synthesis was downregulated in favor of efficient proliferation and maintenance of cells under the stress condition of oxygen. In the anaerobic stage, an efficient conversion of xylose into L-lactic acid was observed from 5.00 to $22.00 \mathrm{~h}$, and the rates of xylose consumption and L-lactic acid accumulation were nearly constant. The results indicated that no carbon catabolite repression (CCR) worked on B. coagulans when the xylose concentration reached $50 \mathrm{~g} \mathrm{~L}^{-1}$. In agreement with the previous study, a high yield of L-lactic acid with xylose $\left(0.99 \mathrm{~g} \mathrm{~g}^{-1}\right)$ was obtained [18], and L-lactic acid titer and productivity reached $46.00 \mathrm{~g} \mathrm{~L}^{-1}$ and $2.71 \mathrm{~g} \mathrm{~L}^{-1} \mathrm{~h}^{-1}$, respectively. Interestingly, the complementary utilization on carbon sources of strain M3013 and LA1507 introduces an effective way to cogenerate ethanol and L-lactic acid based on corn stalk.

\section{The dynamics in gas stripping of ethanol and the effect} of ethanol on the cell growth of $B$. coagulans LA1507

Kinetic analysis was conducted in the gas stripping of ethanol, and initial ethanol concentrations ranging from
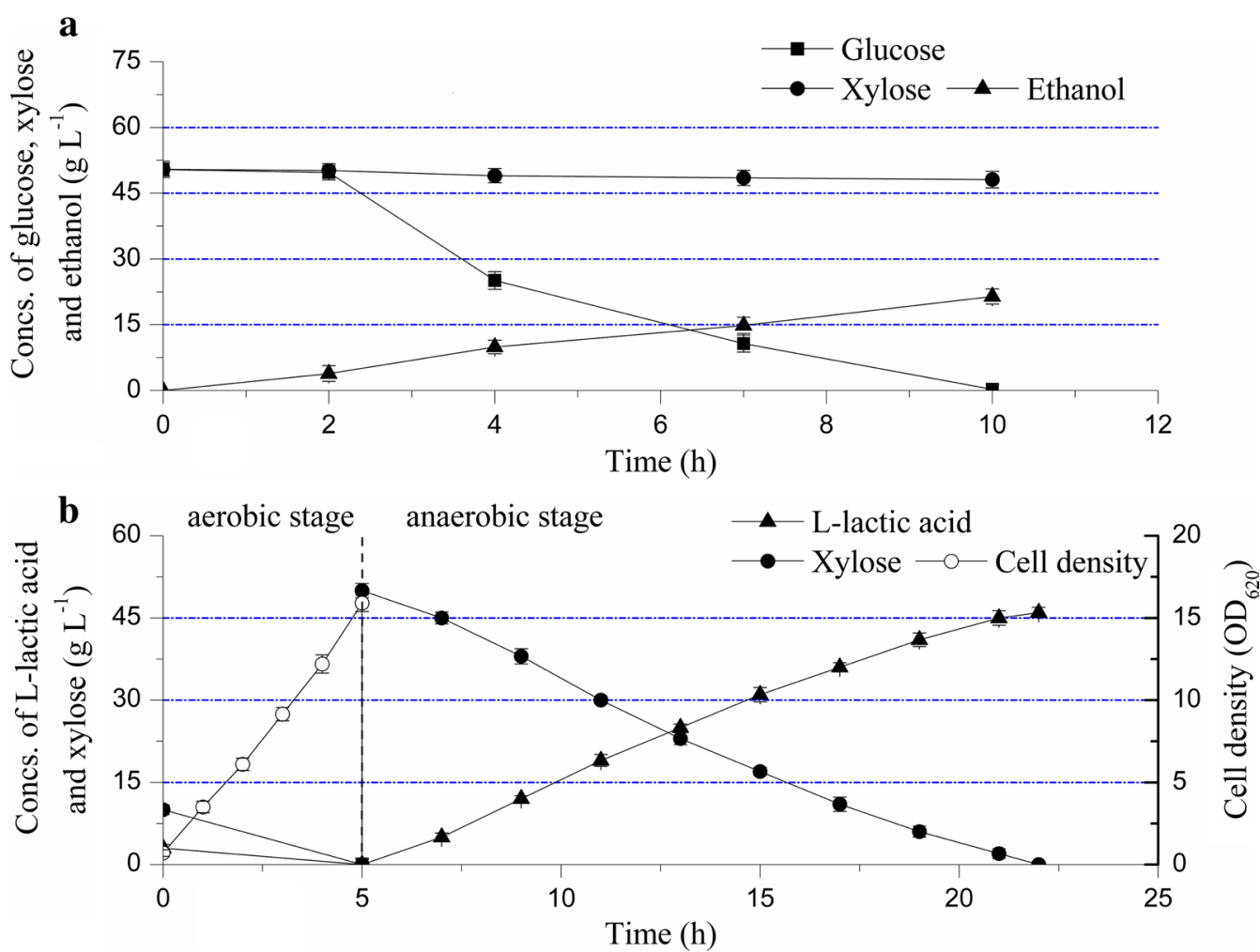

Fig. 1 Sugars utilization and products accumulation in $\mathbf{a}$ ethanol and $\mathbf{b}$ L-lactic acid fermentation. The error bars in the figure indicate the standard deviations of three parallel replicates 

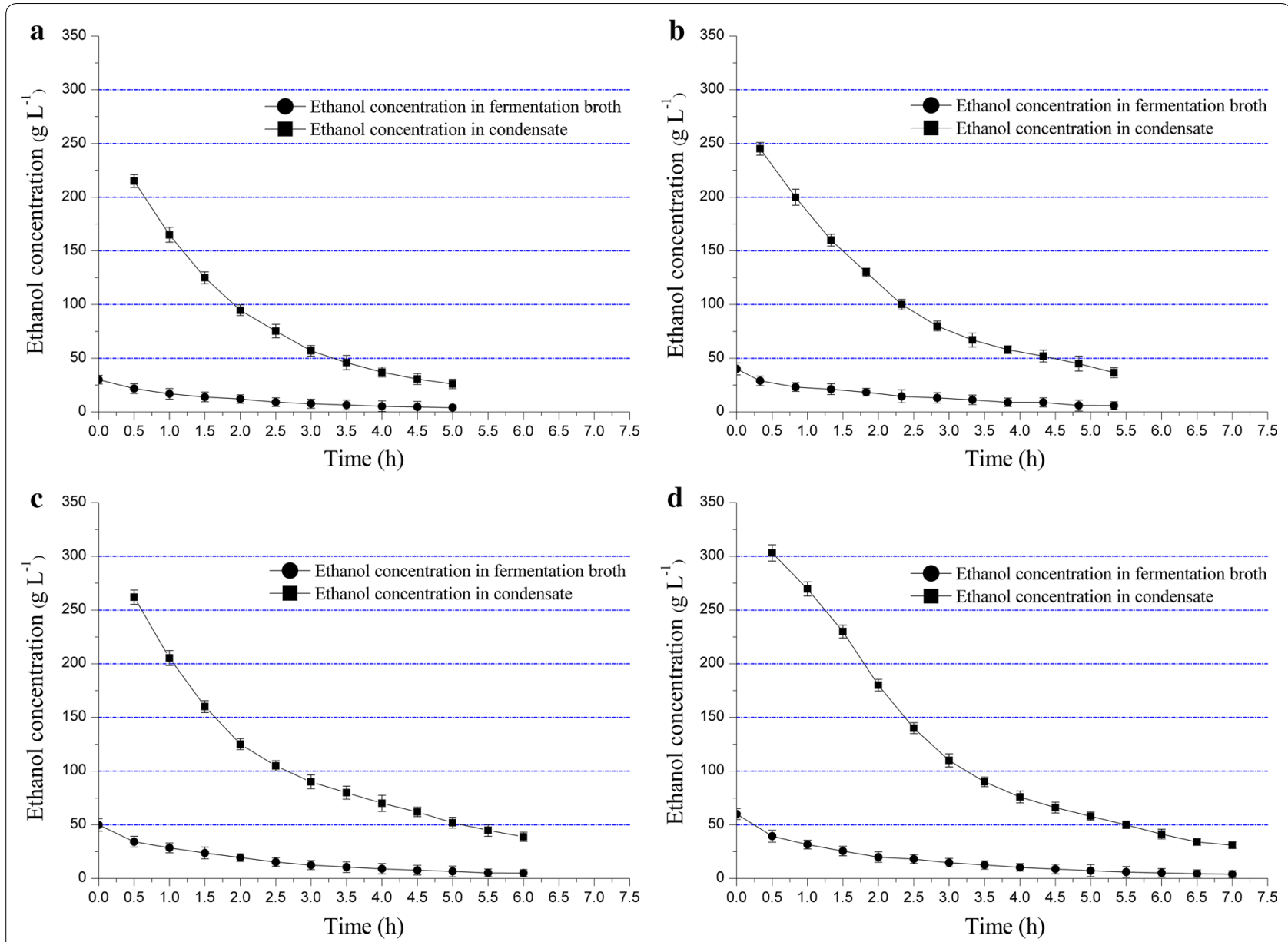

Fig. 2 Kinetic curves of gas stripping of ethanol at different initial ethanol concentrations: a $30.00 \mathrm{~g} \mathrm{~L}^{-1}, \mathbf{b} 40.00 \mathrm{~g} \mathrm{~L}^{-1}, \mathbf{c ~}^{2} 5.00 \mathrm{~g} \mathrm{~L}^{-1}, \mathbf{d} 60.00 \mathrm{~g} \mathrm{~L}^{-1}$. The error bars in the figure indicate the standard deviations of three parallel replicates

30.00 to $60.00 \mathrm{~g} \mathrm{~L}^{-1}$ were adopted. As shown in Fig. 2a, when the initial ethanol concentration was $30.00 \mathrm{~g} \mathrm{~L}^{-1}$, the ethanol content in fermentation broth continuously decreased to $4.00 \mathrm{~g} \mathrm{~L}^{-1}$, and the ethanol concentration in condensate decreased from 215.00 to $26.00 \mathrm{~g} \mathrm{~L}^{-1}$ within 5.00 - $\mathrm{h}$ aeration. When the initial ethanol concentration increased to $40.00 \mathrm{~g} \mathrm{~L}^{-1}, 5.85 \mathrm{~g} \mathrm{~L}^{-1}$ ethanol was achieved in fermentation broth after 5.33-h aeration during which the ethanol content in condensate decreased from 245.00 to $36.60 \mathrm{~g} \mathrm{~L}^{-1}$ (Fig. 2b). In addition, the initial ethanol concentration in condensate reached $262.00 \mathrm{~g} \mathrm{~L}^{-1}$ based on the fermentation broth containing $50.00 \mathrm{~g} \mathrm{~L}^{-1}$ ethanol before aeration, and the ethanol content in condensate and fermentation broth decreased to $38.90 \mathrm{~g} \mathrm{~L}^{-1}$ and $5.00 \mathrm{~g} \mathrm{~L}^{-1}$, respectively (Fig. 2c). Finally, when the initial ethanol concentration was set as $60.00 \mathrm{~g} \mathrm{~L}^{-1}$, a maximum concentration of ethanol in condensate $\left(303.00 \mathrm{~g} \mathrm{~L}^{-1}\right)$ was obtained, and the ethanol content in condensate and fermentation broth decreased to $31.00 \mathrm{~g} \mathrm{~L}^{-1}$ and $4.00 \mathrm{~g}$
$\mathrm{L}^{-1}$, respectively (Fig. $2 \mathrm{~d}$ ). To sum up, the results showed that the initial ethanol content in condensate increased with the rise of ethanol content in fermentor, and the downward trend of ethanol concentration in fermentor slowed down when the ethanol content approximately reached $5.00 \mathrm{~g} \mathrm{~L}^{-1}$.

To reduce the energy consumption of ethanol separation, the gas stripping of ethanol and aerobic culture of B. coagulans LA1507 were simultaneously conducted. As reported by Alzate et al., when the ethanol concentration was about $60.00 \mathrm{~g} \mathrm{~L}^{-1}$, the unit energy costs were energy intensive as it would require $27.89 \mathrm{MJ} \mathrm{L}^{-1}$ ethanol in distillation step [19]. In this study, when the initial ethanol concentration was $50.00 \mathrm{~g} \mathrm{~L}^{-1}$, the integrated value of ethanol content in the condensate could reach about $200.00 \mathrm{~g} \mathrm{~L}^{-1}$ after gas stripping. The increase in ethanol concentration $\left(200.00 \mathrm{~g} \mathrm{~L}^{-1}\right.$ vs. $\left.60.00 \mathrm{~g} \mathrm{~L}^{-1}\right)$ before distillation should reduce about $70.00 \%$ of the energy (19.52 $\mathrm{MJ} \mathrm{L}^{-1}$ ) required for further purification. 
In addition, the effect of ethanol concentration on the cell growth of B. coagulans LA1507 was also studied as shown in Fig. 3. When the initial ethanol concentration was $30.00 \mathrm{~g} \mathrm{~L}^{-1}$, the xylose concentration decreased from 30.00 to $22.00 \mathrm{~g} \mathrm{~L}^{-1}$ during $5.00-\mathrm{h}$ aeration, and the cell density $\left(\mathrm{OD}_{620}\right)$ increased from 0.50 to 8.20 . When the initial ethanol concentration increased to $40.00 \mathrm{~g} \mathrm{~L}^{-1}$, a final cell density $\left(\mathrm{OD}_{620}\right)$ of 8.00 was obtained after $5.33 \mathrm{~h}$, and the xylose concentration decreased from 30.00 to $22.80 \mathrm{~g} \mathrm{~L}^{-1}$. And $50.00 \mathrm{~g} \mathrm{~L}^{-1}$ ethanol was next adopted, the cell density $\left(\mathrm{OD}_{620}\right)$ of B. coagulans LA1507 accumulated to 8.80 within $6.00 \mathrm{~h}$, while the xylose concentration decreased from 30.00 to $21.30 \mathrm{~g} \mathrm{~L}^{-1}$. Although no obvious inhibition effect of ethanol was observed when its initial concentration increased from 30.00 to $50.00 \mathrm{~g} \mathrm{~L}^{-1}$, the aeration time slightly extended to achieve the same level of cell density (Fig. 3b). However, when the initial ethanol concentration was further increased to $60.00 \mathrm{~g}$ $\mathrm{L}^{-1}$, the cell density $\left(\mathrm{OD}_{620}\right)$ was only 6.90 with an inefficient xylose utilization (from 30.00 to $24.20 \mathrm{~g} \mathrm{~L}^{-1}$ ) and an extended aeration time $(7.00 \mathrm{~h})$, indicating a significant inhibition effect of ethanol (Fig. 3b). Taken together, to balance the ethanol titer and the inhibition effect of ethanol on the cell growth of B. coagulans LA1507, the results indicated that the suitable level of initial ethanol concentration was $50.00 \mathrm{~g} \mathrm{~L}^{-1}$ in this study.

\section{The effect of ethanol on L-lactic acid production in anaerobic fermentation of $B$. coagulans LA 1507}

In the hybrid process cogenerating ethanol and L-lactic acid, the ethanol concentration affected the growth of $B$. coagulans LA1507 in the aeration stage, and the cell density of B. coagulans LA1507 had a further effect on L-lactic acid production. As shown in Fig. 4, L-lactic acid production was studied after the aeration stage with different initial ethanol concentrations. With an initial ethanol concentration of $30.00 \mathrm{~g} \mathrm{~L}^{-1}$, xylose $\left(22.00 \mathrm{~g} \mathrm{~L}^{-1}\right)$ in the fermentation broth was totally consumed accumulating $21.50 \mathrm{~g} \mathrm{~L}^{-1} \mathrm{~L}$-lactic acid, and the yield and productivity reached $0.79 \mathrm{~g} \mathrm{~g}^{-1}$ and $2.05 \mathrm{~g} \mathrm{~L}^{-1} \mathrm{~h}^{-1}$, respectively (Fig. 4a). When the initial ethanol concentration was $40.00 \mathrm{~g} \mathrm{~L}^{-1}$, the L-lactic acid concentration reached
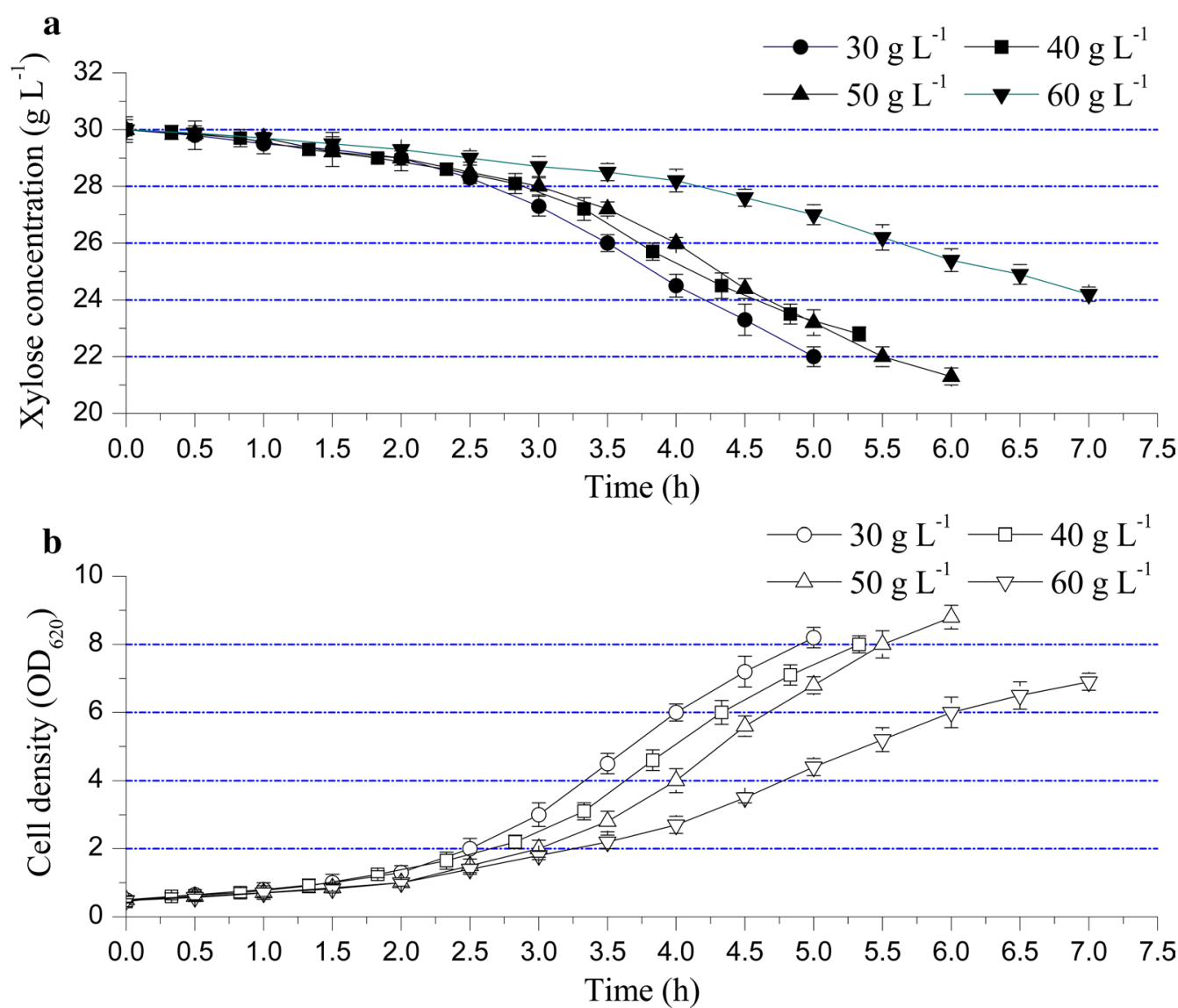

Fig. 3 The cell growth of B. coagulans LA1507 when different initial concentrations of ethanol were adopted. The error bars in the figure indicate the standard deviations of three parallel replicates 


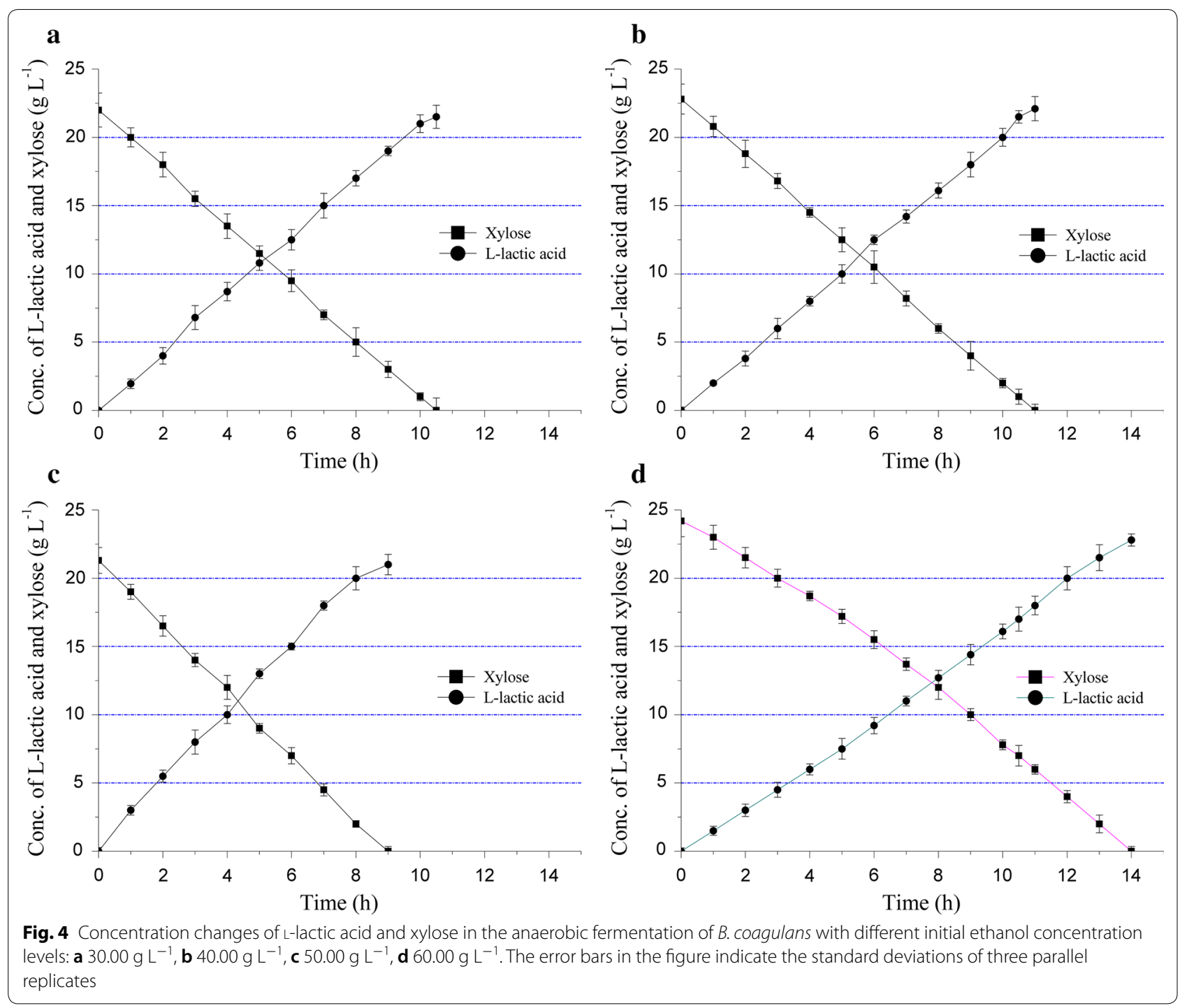

$22.10 \mathrm{~g} \mathrm{~L}^{-1}$ based on the residual xylose $\left(22.80 \mathrm{~g} \mathrm{~L}^{-1}\right)$ after the aeration stage, and a yield of $0.81 \mathrm{~g} \mathrm{~g}^{-1}$ was obtained with a productivity of $2.01 \mathrm{~g} \mathrm{~L}^{-1} \mathrm{~h}^{-1}$ (Fig. $4 \mathrm{~b}$ ).
The similar results obtained in L-lactic acid fermentation at $30.00 \mathrm{~g} \mathrm{~L}^{-1}$ and $40.00 \mathrm{~g} \mathrm{~L}^{-1}$ ethanol were probably caused by the almost same level of cell density (Table 1 ).

Table 1 Comparison of L-lactic acid fermentation characteristics based on simulated substrate and alkali-treated corn stalk (ATCS) hydrolysates

\begin{tabular}{|c|c|c|c|c|c|c|}
\hline Culture & $\begin{array}{l}\text { Initial ethanol } \\
\text { concentration }\left(\mathrm{g} \mathrm{L}^{-1}\right)\end{array}$ & $\begin{array}{l}\text { Aeration time } \\
\text { (h) }\end{array}$ & $\begin{array}{l}\text { Cell density } \\
\left(O D_{620}\right)\end{array}$ & $\begin{array}{l}\text { L-Lactic acid titer } \\
\left(\mathrm{g} \mathrm{L}^{-1}\right)\end{array}$ & $\begin{array}{l}\text { L-Lactic acid yield } \\
\left(\mathrm{g} \mathrm{g}^{-1}\right)\end{array}$ & $\begin{array}{l}\text { L-Lactic acid } \\
\text { productivity } \\
\left(\mathrm{g} \mathrm{L}^{-1} \mathrm{~h}^{-1}\right)\end{array}$ \\
\hline \multirow[t]{4}{*}{ Simulated substrate } & 30.00 & 5.00 & 8.20 & 21.50 & 0.79 & 2.05 \\
\hline & 40.00 & 5.33 & 8.00 & 22.10 & 0.81 & 2.01 \\
\hline & 50.00 & 6.00 & 8.80 & 21.00 & 0.77 & 2.33 \\
\hline & 60.00 & 7.00 & 6.90 & 22.80 & 0.84 & 1.63 \\
\hline \multirow[t]{2}{*}{ ATCS hydrolysates } & 50.50 & 8.00 & 8.80 & 21.50 & 0.76 & 2.08 \\
\hline & 50.30 & 6.50 & 6.90 & 24.25 & 0.86 & 1.96 \\
\hline
\end{tabular}


When the ethanol concentration increased to $50.00 \mathrm{~g} \mathrm{~L}^{-1}$, the L-lactic acid titer was $21.00 \mathrm{~g} \mathrm{~L}^{-1}$, and a maximum of cell density (an $\mathrm{OD}_{620}$ of 8.80 ) was obtained which promoted the increase of productivity $\left(2.33 \mathrm{~g} \mathrm{~L}^{-1} \mathrm{~h}^{-1}\right)$; however, more carbon source was utilized for cell growth, resulting in the decrease of $\mathrm{L}$-lactic acid yield $\left(0.77 \mathrm{~g} \mathrm{~g}^{-1}\right)$ (Fig. 4c). Finally, when the initial ethanol concentration was $60.00 \mathrm{~g} \mathrm{~L}^{-1}$, the $\mathrm{L}$-lactic acid titer reached $22.80 \mathrm{~g} \mathrm{~L}^{-1}$ within an obviously extended fermentation $(14.00 \mathrm{~h})$, and the yield achieved $0.84 \mathrm{~g} \mathrm{~g}^{-1}$; particularly, a relative low cell density $\left(\mathrm{OD}_{620}\right)$ was obtained under the obvious inhibition effect of ethanol $\left(60.00 \mathrm{~g} \mathrm{~L}^{-1}\right)$, which resulted in a low productivity $\left(1.63 \mathrm{~g} \mathrm{~L}^{-1} \mathrm{~h}^{-1}\right)$ (Fig. $\left.4 \mathrm{~d}\right)$. The results indicated that the maximum cell density and productivity were achieved at $50.00 \mathrm{~g} \mathrm{~L}^{-1}$ ethanol; thus, the ethanol concentration in further experiments was set as $50.00 \mathrm{~g}$ $\mathrm{L}^{-1}$ in this study (Table 1 ).

\section{Co-generation of ethanol and L-lactic acid based on corn stalk}

Co-generation of ethanol and L-lactic acid from corn stalk was investigated, and the enzymatic hydrolysates of dry corn stalk (DCS) contained $120.30 \mathrm{~g} \mathrm{~L}^{-1}$ glucose and $33.50 \mathrm{~g} \mathrm{~L}^{-1}$ xylose. As shown in Fig. 5a, ethanol fermentation was conducted before $27.50 \mathrm{~h}$ with an ethanol titer of $50.50 \mathrm{~g} \mathrm{~L}^{-1}$, and the ethanol yield and productivity reached $0.46 \mathrm{~g} \mathrm{~g}^{-1}$ and $1.84 \mathrm{~g} \mathrm{~L}^{-1} \mathrm{~h}^{-1}$, respectively. Moreover, the dilution effect of neutralizer addition caused the slight decrease of xylose concentration (from 33.50 to $30.20 \mathrm{~g} \mathrm{~L}^{-1}$ ). The aerobic culture of B. coagulans LA1507 and the gas stripping of ethanol were performed simultaneously in the aeration stage (from 27.50 to $35.50 \mathrm{~h})$, and the cell density $\left(\mathrm{OD}_{620}\right)$ of $B$. coagulans LA1507 achieved 8.80 consuming $10.20 \mathrm{~g}$ xylose. The ethanol concentration in fermentor decreased from 50.50 to $5.70 \mathrm{~g} \mathrm{~L}^{-1}$ during the gas stripping process, and the ethanol content in condensate declined from 376.40 to $33.00 \mathrm{~g} \mathrm{~L}^{-1}$. Under the same level of ethanol content $\left(50.00 \mathrm{~g} \mathrm{~L}^{-1}\right)$, the increase of the initial ethanol concentration and the decrease of the final ethanol concentration in condensates comparing to the previous results of kinetic experiment $\left(262.00 \mathrm{~g} \mathrm{~L}^{-1}\right.$ and $\left.38.90 \mathrm{~g} \mathrm{~L}^{-1}\right)$ indicated that the composition difference of culture medium may contribute to the gas stripping of ethanol, which need to be further studied. The anaerobic fermentation of L-lactic acid was conducted from 35.50 to $45.50 \mathrm{~h}$, and the L-lactic acid titer reached $21.50 \mathrm{~g} \mathrm{~L}^{-1}$ with a productivity of $2.08 \mathrm{~g} \mathrm{~L}^{-1} \mathrm{~h}^{-1}$; however, the high cell density $\left(\mathrm{OD}_{620}=8.80\right)$ of $B$. coagulans $\mathrm{LA} 1507$ resulted in a relative low product yield $\left(0.76 \mathrm{~g} \mathrm{~g}^{-1}\right)$.

A pre-aeration process was further introduced to reduce both ethanol inhibition effect on $B$. coagulans LA1507 and the aeration time. As shown in Fig. 5b, during the ethanol fermentation (before $27.50 \mathrm{~h}$ ), an ethanol titer of $50.30 \mathrm{~g} \mathrm{~L}^{-1}$ was obtained, and the ethanol yield and productivity reached $0.46 \mathrm{~g} \mathrm{~g}^{-1}$ and $1.83 \mathrm{~g}$ $\mathrm{L}^{-1} \mathrm{~h}^{-1}$, respectively. The pre-aeration was conducted from 27.50 to $30.00 \mathrm{~h}$, and the ethanol concentration in condensate declined from 372.00 to $165.00 \mathrm{~g} \mathrm{~L}^{-1}$; moreover, the ethanol concentration in fermentor decreased by $60.24 \%$, which would significantly reduce the ethanol inhibition effect on B. coagulans LA1507. The gas stripping of ethanol and the aerobic culture of $B$. coagulans LA1507 were simultaneously conducted from 30.00 to $34.00 \mathrm{~h}$. The ethanol concentration in fermentor further decreased from 20.00 to $6.50 \mathrm{~g} \mathrm{~L}^{-1}$, and the final ethanol content in condensate was $37.50 \mathrm{~g} \mathrm{~L}^{-1}$. In addition, the cell density $\left(\mathrm{OD}_{620}\right)$ of $B$. coagulans LA1507 increased rapidly from 0.42 to 6.90 within $4.00 \mathrm{~h}$, and the relative low level of cell density contributes to the increase of L-lactic acid yield, while reducing the xylose consumption for cell growth. In L-lactic acid fermentation (from 34.00 to $46.00 \mathrm{~h}$ ), the residual xylose was totally consumed with a product titer of $24.25 \mathrm{~g} \mathrm{~L}^{-1}$, and the productivity achieved $1.96 \mathrm{~g} \mathrm{~L}^{-1} \mathrm{~h}^{-1}$. As expected, the $\mathrm{L}$-lactic acid yield increased to $0.86 \mathrm{~g} \mathrm{~g}^{-1}$ when the cell density was controlled at 6.90 .

Comparing with the co-generation process without pre-aeration, when a pre-aeration was adopted, the total aeration time decreased from 8.00 to $6.50 \mathrm{~h}$, and the L-lactic acid yield significantly increased from 0.76 to $0.86 \mathrm{~g} \mathrm{~g}^{-1}$ (Table 1). Interestingly, although the cell density was controlled at a low level with pre-aeration $\left(\mathrm{OD}_{620}=6.90\right)$, the productivity obtained $\left(1.96 \mathrm{~g} \mathrm{~L}^{-1}\right.$ $\mathrm{h}^{-1}$ ) was near that of the process without pre-aeration $\left(2.08 \mathrm{~g} \mathrm{~L}^{-1} \mathrm{~h}^{-1}\right)$, indicating the reduced ethanol inhibition effect on B. coagulans LA1507 fermentation. A mass balance of the experiment process was evaluated, and $135.56 \mathrm{~g}$ ethanol and $70.61 \mathrm{~g} \mathrm{~L}$-lactic acid were finally obtained from $1.00 \mathrm{~kg}$ DCS (Fig. 6). It is worth to mention that a considerable amount of fermentable sugars remaining in the alkaline waste liquid and the hydrolysis residual was still not utilized effectively, which needs further research.

\section{Discussion}

Two-stage fermentation has been widely studied for the cogeneration of hydrogen and methane, and the residual $\mathrm{H}_{2}$-producing solution riching in volatile fatty acids has been reutilized by the methanogen community for methane production to increase the energy conversion efficiency [20-22]. In this study, a two-stage fermentation was conducted to efficiently utilize the residual xylose in ethanol-producing solution, and the feasibility of cogenerating ethanol and L-lactic acid was studied, which has been rarely reported. 

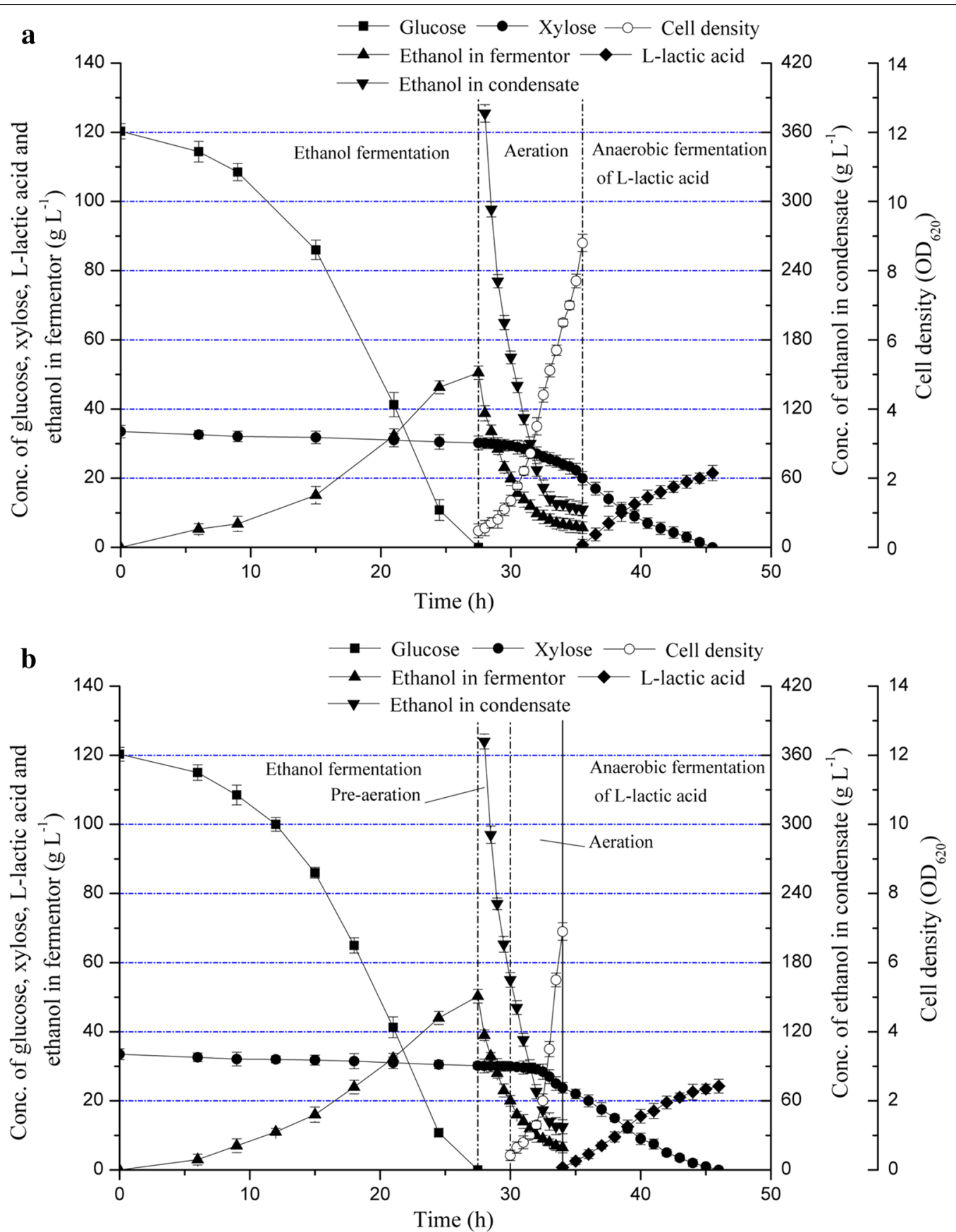

Fig. 5 Co-generation of ethanol and L-lactic acid from corn stalk hydrolysates: $\mathbf{a}$ without pre-aeration and $\mathbf{b}$ with pre-aeration. The error bars in the figure indicate the standard deviations of three parallel replicates

The lack of xylose reductase and xylitol dehydrogenase activities in native $S$. cerevisiae leads to a defect of xylose utilization [23]. Currently, the bacterial conversion of xylose into ethanol has been studied mostly by the recombinant microorganisms; however, ethanol inhibition and fastidious requirements for aerobic condition of metabolic engineering strains limited the large-scale industrial application [24]. Thus, the efficient utilization of biomass resources by process improvement under the concept of biological refining was proposed in this study.

In agreement with the previous reports, it was confirmed that the native strain S. cerevisiae M3013 does 


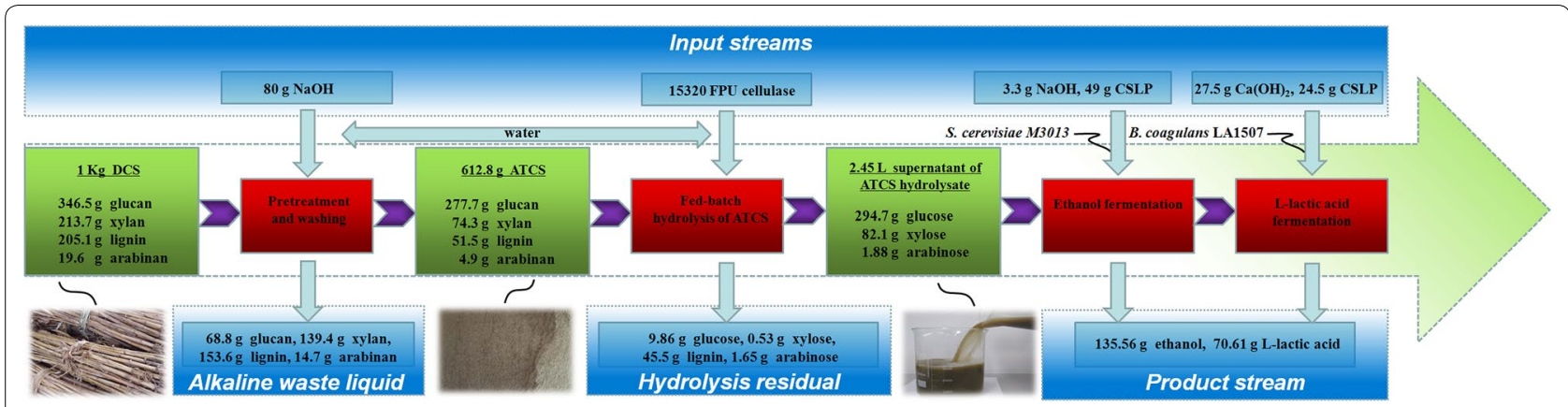

Fig. 6 The mass balance of the experimental process based on $1.00 \mathrm{~kg}$ DCS

not utilize xylose (Fig. 1a). Comparing with ethanol fermentations under very high gravity (VHG) conditions $[25,26]$, the ethanol yield and productivity obtained in this study indicated that no inhibition effect was generated with the carbon source containing $120.30 \mathrm{~g} \mathrm{~L}^{-1}$ glucose and $33.50 \mathrm{~g} \mathrm{~L}^{-1}$ xylose. In addition, the efficient utilization of xylose by B. coagulans LA1507 in L-lactic acid fermentation was observed (Fig. 1b). Owing to its advantageous characteristics in terms of growing and fermenting at high temperature $\left(50.00-60.00{ }^{\circ} \mathrm{C}\right)$, simple nutrition requirement and high optical purity of the product [27], B. coagulans LA1507 was used for nonsterilized fermentation of L-lactic acid following the ethanol production. The complementary utilization in carbon source of strain M3013 and strain LA1507 provides us important insights to elucidate the mechanism of the hybrid process containing a two-stage fermentation.

A significant source of cost and energy consumption in current ethanol production is the dewatering and drying of ethanol [28]. Thus, the gas stripping of ethanol and the aerobic culture of $B$. coagulans LA1507 were simultaneously conducted in this study aiming to reduce the separation cost. According to Raoult's law, the vapor pressure of a volatile compound in a dilute solution increased linearly with its molar concentration in the solution. In ABE separation process of butanol fermentation, Xue et al. found that the stripping rate decreased with the reduced $\mathrm{ABE}$ concentration in the solution and the gas stripping became ineffective when $\mathrm{ABE}$ concentration was below $5.00 \mathrm{~g} \mathrm{~L}^{-1}$ [29]. The same phenomenon was also observed in the present study, and the final ethanol concentration in fermentor after gas stripping was also near the level of $5.00 \mathrm{~g} \mathrm{~L}^{-1}$. In this study, under the optimized conditions, the integrated value of ethanol content in condensate reached about $200.00 \mathrm{~g} \mathrm{~L}^{-1}$ which was four times of ethanol titer after fermentation. The highly concentrated condensate that far exceeded ethanol titer would significantly contribute to reducing ethanol separation cost.
Lactic acid bacteria (LAB) are Gram-positive bacteria which can survive and grow in ethanol-containing environments [30]; however, the toxic effect of ethanol on cell membrane can not be ignored, which further inhibits the growth and viability of bacteria [31]. Thus, the gas stripping of ethanol was conducted to alleviate the inhibition effect on B. coagulans LA1507, and the results obtained imply that no significant ethanol inhibition on B. coagulans LA1507 growth and L-lactic acid production was generated when the initial ethanol concentration reached $50.00 \mathrm{~g} \mathrm{~L}^{-1}$. Moreover, as shown in Fig. 5, when a pre-aeration was introduced in the cogeneration process based on the hydrolysates of alkali-treated corn stalk (ATCS), the aeration time significantly decreased from 7.00 to $4.00 \mathrm{~h}$ to achieve the same level of cell density $\left(\mathrm{OD}_{620}=6.90\right)$. In addition, the L-lactic acid productivity with low cell density $\left(\mathrm{OD}_{620}=6.90\right)$ achieved $1.96 \mathrm{~g}$ $\mathrm{L}^{-1} \mathrm{~h}^{-1}$ which was near $2.08 \mathrm{~g} \mathrm{~L}^{-1} \mathrm{~h}^{-1}$ obtained with high cell density $\left(\mathrm{OD}_{620}=8.80\right)$. These data imply that the gas stripping of ethanol promotes both the cell growth of $B$. coagulans LA1507 and the production of L-lactic acid.

The yeast residue was removed from the broth by centrifugation after ethanol fermentation, which facilitated the cell density determination of B. coagulans LA1507. However, in fact, if the cells of $S$. cerevisiae retained in the fermentation broth, the high temperature of L-lactic acid fermentation in this study could contribute to the autolysis of yeast [32]. And it has been widely reported that the yeast autolysates riching in amino acids and vitamins has a significant positive effect on lactic acid production [27, 33-35]. The utilization of yeast autolysate as nitrogen source would both reduce the raw material cost and intensify the hybrid process, which need to be further studied.

\section{Conclusion}

In this paper, the hybrid process containing a twostage fermentation was investigated for cogeneration of ethanol and L-lactic acid based on corn stalk. The gas 
stripping of ethanol and the effect of ethanol on L-lactic acid fermentation were studied, and the optimized ethanol titer was found to be $50.00 \mathrm{~g} \mathrm{~L}^{-1}$. Using ATCS hydrolysates as substrate, an ethanol titer of $50.30 \mathrm{~g} \mathrm{~L}^{-1}$ was obtained, and the yield and productivity of ethanol reached $0.46 \mathrm{~g} \mathrm{~g}^{-1}$ and $1.83 \mathrm{~g} \mathrm{~L}^{-1} \mathrm{~h}^{-1}$, respectively. In addition, the hybrid process provided a $\mathrm{L}$-lactic acid titer of $24.25 \mathrm{~g} \mathrm{~L}^{-1}$ with a productivity of $1.96 \mathrm{~g} \mathrm{~L}^{-1} \mathrm{~h}^{-1}$. Comparing with the process without pre-aeration, the total aeration time decreased from 8.00 to $6.50 \mathrm{~h}$ and the L-lactic acid yield significantly increased from 0.76 to $0.86 \mathrm{~g} \mathrm{~g}^{-1}$ in the process with pre-aeration, while keeping the productivity at the same level. A mass balance of the experiment procedure was evaluated, and $135.56 \mathrm{~g}$ ethanol and $70.61 \mathrm{~g} \mathrm{~L}$-lactic acid were finally obtained from $1.00 \mathrm{~kg}$ DCS. These findings suggest that the efficient utilization of biomass resources can be realized by process improvement for cogeneration of ethanol and L-lactic acid under the concept of biological refining.

\section{Methods}

\section{Raw materials}

Corn stalk was harvested in Zibo, Shandong of China. The chopped stalk was dried at $80.00{ }^{\circ} \mathrm{C}$ to a constant weight and milled to about $850.00 \mu \mathrm{m}$ using a laboratory grinder. The DCS was composed of $34.65 \%$ glucan, $21.37 \%$ xylan, $1.96 \%$ arabinan and $20.51 \%$ lignin. The DCS was further pretreated by $2.00 \%(\mathrm{w} / \mathrm{v}) \mathrm{NaOH}$ at $118.00{ }^{\circ} \mathrm{C}$ for $1.33 \mathrm{~h}$, and the solids loading was kept at $10.00 \%(\mathrm{w} / \mathrm{v})$. The solid fraction obtained by filtration after pretreatment was washed with water until the $\mathrm{pH}$ value of the residue attained 7.00. The ATCS contained $45.32 \%$ glucan, $12.12 \%$ xylan, $0.80 \%$ arabinan and $8.40 \%$ lignin, and $612.80 \mathrm{~g}$ ATCS (dry weight) could be obtained from $1.00 \mathrm{~kg}$ DCS. Cellulase, which had a specific activity of 78.00 FPU mL ${ }^{-1}$ according to the manufacturers' data, was used for the enzymatic hydrolysis of ATCS, and it was provided by Tianfeng Bioengineering Corporation (Hebei, China).

Yeast extract (YE), beef extract and soya peptone were purchased from Aobox Biotechnology Co., Ltd. (Beijing, China). Malt extract was provided by Lifa Long Chemical Technology Co., Ltd. (Tianjin, China). Corn steep liquor powder (CSLP) was purchased from Beijing Mannafeed International Group (Beijing, China). All other chemicals used were reagent grade.

\section{Strains and culture media}

Saccharomyces cerevisiae M3013 was screened by the research group of Tan in Beijing University of Chemical Technology. One B. coagulans strain was isolated and designated as LA1507 as reported in the previous study [18]. Both strains were maintained at the Key Lab of Bioprocess of Beijing.
For S. cerevisiae M3013, the agar medium contained $20.00 \mathrm{~g} \mathrm{~L}^{-1}$ glucose, $3.00 \mathrm{~g} \mathrm{~L}^{-1}$ malt extract, $3.00 \mathrm{~g} \mathrm{~L}^{-1}$ YE, $5.00 \mathrm{~g} \mathrm{~L}^{-1}$ soy peptone and $20.00 \mathrm{~g} \mathrm{~L}^{-1}$ agar, and the medium for inoculum preparation consisted of $0.80 \mathrm{~g}$ $\mathrm{L}^{-1}$ sucrose, $20.00 \mathrm{~g} \mathrm{~L}^{-1}$ glucose, $5.00 \mathrm{~g} \mathrm{~L}^{-1}$ soy peptone and $3.00 \mathrm{~g} \mathrm{~L}^{-1}$ YE. To evaluate the capability of carbon source utilization, S. cerevisiae M3013 was precultured in the medium containing $50.00 \mathrm{~g} \mathrm{~L}^{-1}$ glucose, $50.00 \mathrm{~g}$ $\mathrm{L}^{-1}$ xylose, $15.00 \mathrm{~g} \mathrm{~L}^{-1} \mathrm{YE}, 2.05 \mathrm{~g} \mathrm{~L}^{-1} \mathrm{MgSO}_{4} \cdot 7 \mathrm{H}_{2} \mathrm{O}$ and $0.50 \mathrm{~g} \mathrm{~L}^{-1} \mathrm{KH}_{2} \mathrm{PO}_{4}$. The fermentation medium based on corn stalk consisted of ATCS hydrolysates (containing $120.30 \mathrm{~g} \mathrm{~L}^{-1}$ glucose and $33.50 \mathrm{~g} \mathrm{~L}^{-1}$ xylose) and $20.00 \mathrm{~g}$ $\mathrm{L}^{-1}$ CSLP.

For B. coagulans LA1507, the media for agar slant and inoculum were prepared as reported in the previous work [36]. To evaluate the capability of xylose utilization, $B$. coagulans LA1507 was precultured in the medium containing $15.00 \mathrm{~g} \mathrm{~L}^{-1} \mathrm{YE}, 1.00 \mathrm{~g} \mathrm{~L}^{-1} \mathrm{NH}_{4} \mathrm{SO}_{4}, 0.40 \mathrm{~g} \mathrm{~L}^{-1}$ $\mathrm{KH}_{2} \mathrm{PO}_{4}, 0.30 \mathrm{~g} \mathrm{~L}^{-1} \mathrm{MgSO}_{4} \cdot 7 \mathrm{H}_{2} \mathrm{O}$ and $2.50 \mathrm{~g} \mathrm{~L}^{-1} \mathrm{NaCl}$, moreover, the initial xylose concentration in aerobic stage was $10.00 \mathrm{~g} \mathrm{~L}^{-1}$, and $50.00 \mathrm{~g} \mathrm{~L}^{-1}$ xylose was added in the anaerobic stage for L-lactic acid production. To investigate the effect of ethanol on the cell growth of B. coagulans LA1507 and the production of L-lactic acid, different ethanol concentrations ranging from 30.00 to $60.00 \mathrm{~g} \mathrm{~L}^{-1}$ were adopted, and the medium also contained $30.00 \mathrm{~g}$ $\mathrm{L}^{-1}$ xylose and $10.00 \mathrm{~g} \mathrm{~L}^{-1}$ CSLP. The medium for $\mathrm{L}$-lactic acid production based on corn stalk was composed of the residual liquid after ethanol fermentation (containing $30.00 \mathrm{~g} \mathrm{~L}^{-1}$ xylose) and $10.00 \mathrm{~g} \mathrm{~L}^{-1}$ CSLP.

The $\mathrm{pH}$ of all culture media in this study was adjusted to 6.25 using $1.00 \mathrm{~mol} \mathrm{~L}^{-1} \mathrm{HCl}$ or $40.00 \%$ (w/w) $\mathrm{NaOH}$ before use. Agar slants, inoculums, preculture media and the medium based on corn stalk for ethanol fermentation were sterilized at $116.00{ }^{\circ} \mathrm{C}$ for $0.33 \mathrm{~h}$. However, the L-lactic acid fermentation medium deriving from residual liquid after ethanol fermentation was not sterilized.

\section{Cultivation conditions}

Saccharomyces cerevisiae M3013 and B. coagulans LA1507 were maintained on agar slants which were stored at $4.00{ }^{\circ} \mathrm{C}$. Stock cultures were transferred monthly, and strains of M3013 and LA1507 were grown on slants at $28.00^{\circ} \mathrm{C}$ and $50.00{ }^{\circ} \mathrm{C}$, respectively.

Inoculum preparation was conducted in conical flasks with a working volume of $100.00 \mathrm{~mL}$. The seed culture of S. cerevisiae M3013 was incubated at $28.00{ }^{\circ} \mathrm{C}$ for $20.00 \mathrm{~h}$, and the rotation speed was $180.00 \mathrm{rpm}$. The temperature and rotation speed during inoculum preparation of B. coagulans LA1507 were maintained at $50.00{ }^{\circ} \mathrm{C}$ and $150.00 \mathrm{rpm}$, respectively, and the incubation time was $20.00 \mathrm{~h}$. The incubation rate of both strains was $10.00 \%$ $(\mathrm{v} / \mathrm{v})$. 
Both of S. cerevisiae M3013 and B. coagulans LA1507 were precultured to examine the capacity of carbon sources utilization. Batch fermentations were conducted in a 5-L fermentor (SGB-5L, Changzhou Sungod Biotechnology \& Engineering Equipment Co., Ltd., Jiangsu, China) with a working volume of $2.00 \mathrm{~L}$. Ethanol fermentation was conducted at $30.00{ }^{\circ} \mathrm{C}$ with an agitation speed of $120.00 \mathrm{rpm}$, and the $\mathrm{pH}$ was kept at 6.00 by $40.00 \%$ (w/w) $\mathrm{NaOH}$. In the aerobic stage of L-lactic acid fermentation, the aeration rate and agitation speed were maintained at $2.00 \mathrm{vvm}$ and $400.00 \mathrm{rpm}$, respectively, and an agitation speed of $260.00 \mathrm{rpm}$ was adopted in the following anaerobic fermentation. A temperature of $50.00{ }^{\circ} \mathrm{C}$ was adopted and the $\mathrm{pH}$ was maintained at 6.25 by $33.00 \%(w / w) \mathrm{Ca}(\mathrm{OH})_{2}$.

To investigate the effect of ethanol on the cell growth of B. coagulans LA1507 and the production of L-lactic acid, batch fermentations were conducted with different initial ethanol concentrations $\left(30.00 \mathrm{~g} \mathrm{~L}^{-1}, 40.00 \mathrm{~g} \mathrm{~L}^{-1}\right.$, $50.00 \mathrm{~g} \mathrm{~L}^{-1}$ and $60.00 \mathrm{~g} \mathrm{~L}^{-1}$ ), and a $5 \mathrm{~L}$ fermentor (SGB5L, Changzhou Sungod Biotechnology \& Engineering Equipment Co., Ltd., Jiangsu, China) with a working volume of $1.00 \mathrm{~L}$ (containing $30.00 \mathrm{~g} \mathrm{~L}^{-1}$ xylose and $10.00 \mathrm{~g}$ $\mathrm{L}^{-1}$ CSLP) was used, while keeping all other conditions identical to those adopted in the preculture of $B$. coagulans LA1507. The ethanol removed by gas stripping was collected by a condenser soaked in liquid nitrogen.

\section{The fed-batch hydrolysis of ATCS}

A fed-batch process was conducted in the enzymatic hydrolysis of ATCS, and a cellulase dose of 25.00 FPU g $\mathrm{g}^{-1}$ ATCS was adopted. The enzymatic hydrolysis was conducted at $55.00{ }^{\circ} \mathrm{C}$ with an agitation speed of $150.00 \mathrm{rpm}$, and the $\mathrm{pH}$ was maintained at 5.00 by $36.00 \% \mathrm{HCl}$. A 7-L fermentor (BLBIO-7GJ, Bailun Biological Technology Co., Ltd., Shanghai, China) with a working volume of $5.00 \mathrm{~L}$ was used as hydrolysis tank, and the final loading of ATCS was $25.00 \%$ (w/v). Finally, solid residue was removed from the enzymatic hydrolysates by vacuum filtration, and the ATCS hydrolysates normally contained $120.30 \mathrm{~g} \mathrm{~L}^{-1}$ glucose and $33.50 \mathrm{~g} \mathrm{~L}^{-1}$ xylose.

\section{The hybrid process for co-generation of ethanol and L-lactic acid based on corn stalk}

The hybrid process involved in cogenerating ethanol and L-lactic acid is shown in Fig. 7. A 5-L fermentor (SGB5L, Changzhou Sungod Biotechnology \& Engineering Equipment Co., Ltd., Jiangsu, China) was use for ethanol and L-lactic acid fermentation. A working volume of $2.00 \mathrm{~L}$ was adopted in ethanol fermentation, and the fermentation broth obtained was centrifuged at $6275.00 \times g$ for $0.17 \mathrm{~h}$ to remove the cell residue. The supernatant $(1.00 \mathrm{~L})$ of ethanol fermentation broth was further used for L-lactic acid production. Particularly, the air pumped into the fermentor was used as both the carrier gas for single-pass gas stripping of ethanol and the oxygen provider for aerobic growth of B. coagulans LA1507, which could significantly reduce the energy cost of ethanol separation. All other conditions were identical to those adopted in the preculture of S. cerevisiae M3013 and B. coagulans LA1507. Liquid nitrogen was used as coolant to condense and recover the ethanol in stripping gas.

\section{Analytical methods}

L-lactic acid was determined by SBA-40C biosensor analyzer (Institute of Biology, Shandong Province Academy

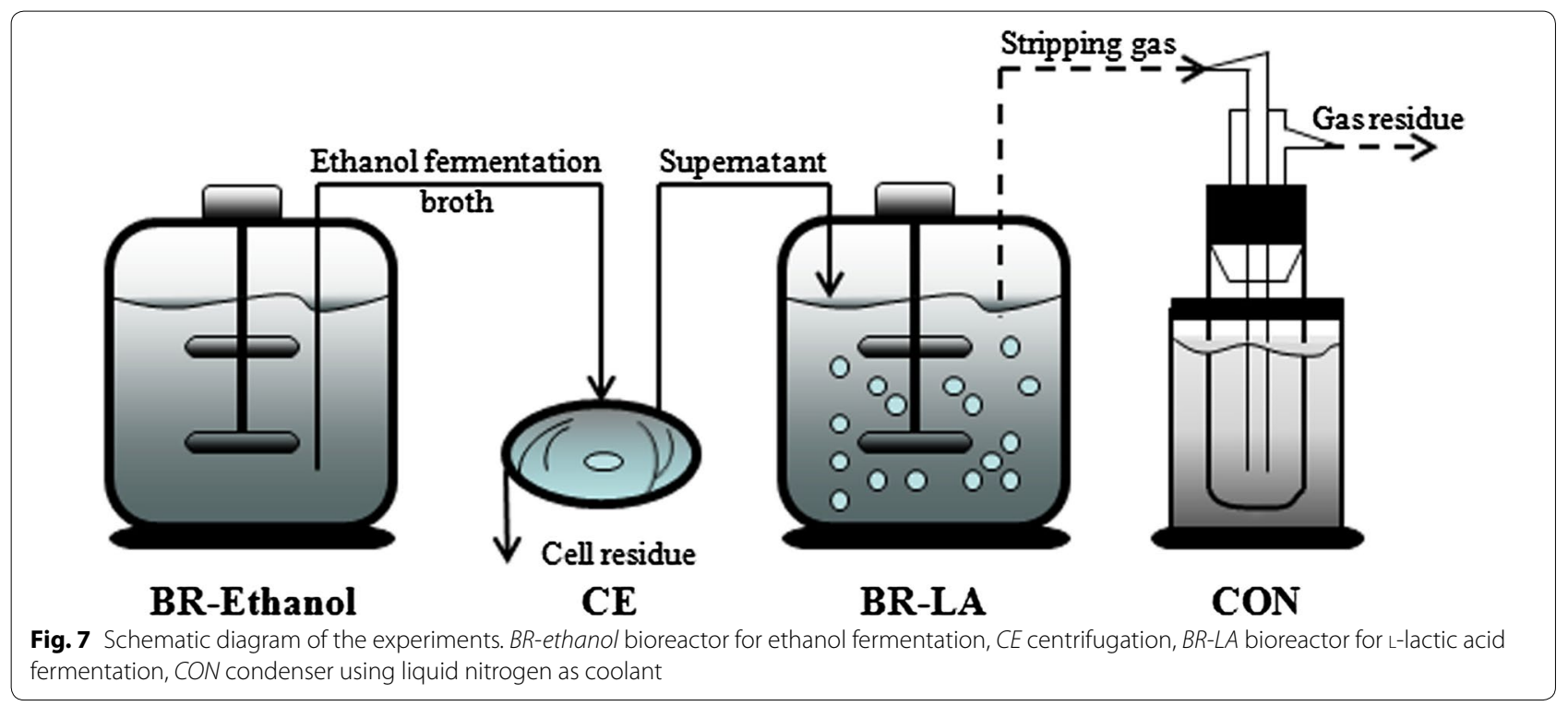


of Sciences, Shandong, China) [37]. Before determination, insoluble substances were removed by centrifugation, and the samples were further diluted with distilled water. A spectrophotometer (UV-1100, Beijing Eternal Cause Instrument Co., Ltd., Beijing, China) was used to measure the cell density of B. coagulans LA1507 at a wavelength of $620.00 \mathrm{~nm}$ [38]. The yields of ethanol and L-lactic acid were calculated according to Eqs. (1) and (2), respectively:

$$
\begin{aligned}
& Y_{\mathrm{E}}=\frac{W_{\text {ethanol }}}{W_{\text {glucose }}} \times 100 \% ; \\
& Y_{\mathrm{LA}}=\frac{W_{\mathrm{LA}}}{W_{\text {glucose }}+W_{\text {xylose }}} \times 100 \% ;
\end{aligned}
$$

where $Y_{\mathrm{E}}$ and $Y_{\mathrm{LA}}$ represent the yields of ethanol and L-lactic acid based on carbon sources in this study. $W_{\text {ethanol }}$ and $W_{\mathrm{LA}}$ are the total amount of ethanol and L-lactic acid produced, and $W_{\text {glucose }}$ and $W_{\text {xylose }}$ are the amount of glucose and xylose consumed in the fermentation. In this study, for batch fermentations of ethanol and L-lactic acid, the amount of glucose or xylose consumed was calculated according to Eq. (3):

$$
W_{g / x}=C_{i} \cdot V_{i}-C_{f} \cdot V_{f}-\sum_{1}^{n} C_{t} \cdot V_{t},
$$

where $W_{g / x}$ represents the amount of consumed glucose or xylose. $C_{i}$ and $C_{f}$ are the initial and final concentration of glucose or xylose, and $V_{i}$ and $V_{f}$ are the initial and final volume of fermentation broth. Particularly, $C_{t}$ and $V_{t}$ are the concentration and volume of a sample, and $\mathrm{n}$ represents the total sampling number.

The concentration of monosaccharides was determined by high-performance liquid chromatography (HPLC) equipped with a HPX-87P carbohydrate analysis column (Bio-Rad Labs, USA) and a refractive index (RI) detector, and the determination temperature was maintained at $80.00{ }^{\circ} \mathrm{C}$ using deionized water as mobile-phase $\left(36.00 \mathrm{~mL} \mathrm{~h}^{-1}\right)$ [39]. Ethanol concentration was analyzed based on the method of Cai et al. [40]. Moreover, for evaluation of mass balance in the experiment process, the analytical methods and calculation basis of carbohydrates and lignin in the fiber and liquid phases were according to the National Renewable Energy Laboratory (NREL) protocol [41].

\footnotetext{
Abbreviations

LAB: lactic acid bacteria; DCS: dry corn stalk; ATCS: alkali-treated corn stalk; YE: yeast extract; CSLP: corn steep liquor powder; BR-Ethanol: bioreactor for ethanol fermentation; CE: centrifugation; BR-LA: bioreactor for L-lactic acid fermentation; CON: condenser using liquid nitrogen as coolant; RI: refractive index; HPLC: high-performance liquid chromatography; NREL: National Renewable Energy Laboratory.
}

\section{Authors' contributions}

YW designed the whole scheme of the study and conducted the experiments, $J \mathrm{~L}$ and $\mathrm{GZ}$ helped to analyze and interpret the experimental data. YW wrote the manuscript, and DC helped to revise. All authors read and approved the final manuscript.

\section{Author details}

${ }^{1}$ Fermentation Engineering Technology Research Center of Heibei Province, College of Bioscience \& Bioengineering, Hebei University of Science and Technology, Shijiazhuang 050000, People's Republic of China. ${ }^{2}$ National Energy R\&D Center for Biorefinery, Beijing University of Chemical Technology, Beijing 100029, People's Republic of China.

\section{Acknowledgements}

We would like to acknowledge the establishment of the Fermentation Engineering Technology Research Center of Heibei Province. This work was supported by the natural science foundation of Hebei province (Grant No. C2016208052) and the national nature science foundation of China (Grant Nos. 21676014 and 21706008).

\section{Competing interests}

The authors declare that they have no competing interests.

\section{Availability of data and materials}

All data generated or analyzed during this study are included in this published article.

\section{Consent for publication}

Not applicable.

\section{Ethics approval and consent to participate} Not applicable.

\section{Publisher's Note}

Springer Nature remains neutral with regard to jurisdictional claims in published maps and institutional affiliations.

Received: 30 August 2018 Accepted: 3 December 2018 Published online: 18 December 2018

\section{References}

1. Qi GX, Xiong L, Huang C, Chen XF, Lin XQ, Chen XD. Solvents production from a mixture of glucose and xylose by mixed fermentation of Clostridium acetobutylicum and Saccharomyces cerevisiae. Appl Biochem Biotechnol. 2015;177:996-1002.

2. Farrell AE, Plevin RJ, Turner BT, Jones AD, O'hare M, Kammen DM. Ethanol can contribute to energy and environmental goals. Science. 2006;311:506-8.

3. Olsson L, Hahn-Hägerdal B. Fermentation of lignocellulosic hydrolysates for ethanol production. Enzyme Microb Technol. 1996;18:312-31.

4. Martín C, Galbe M, Wahlbom CF, Hahn-Hägerdal B, Jönsson LJ. Ethanol production from enzymatic hydrolysates of sugarcane bagasse using recombinant xylose-utilising Saccharomyces cerevisiae. Enzyme Microb Technol. 2002;31:274-82.

5. Brat D, Boles E, Wiedemann B. Functional expression of a bacterial xylose isomerase in Saccharomyces cerevisiae. Appl Environ Microbiol. 2009;75:2304-11.

6. Jin YS, Lee TH, Choi YD, Ryu YW, Seo JH. Conversion of xylose to ethanol by recombinant Saccharomyces cerevisiae containing genes for xylose reductase and xylitol dehydrogenase from Pichia stipitis. J Micorbiol Biotechnol. 2000;10:564-7.

7. Karhumaa K, Sanchez RG, Hahn-Hägerdal B, Gorwa-Grauslund MF. Comparison of the xylose reductase-xylitol dehydrogenase and the xylose isomerase pathways for xylose fermentation by recombinant Saccharomyces cerevisiae. Microb Cell Fact. 2007;6:5.

8. Lee SH, Kodaki T, Park YC, Seo JH. Effects of NADH-preferring xylose reductase expressionon ethanol production from xylose in 
xylose-metabolizing recombinant Saccharomyces cerevisiae. J Biotechnol. 2012;158:184-91.

9. Kim SR, Ha SJ, Kong II, Jin YS. High expression of XYL2 coding for xylitol dehydrogenase is necessary for efficient xylose fermentation by engineered Saccharomyces cerevisiae. Metab Eng. 2012;14:336-43.

10. Kim SR, Park YC, Jin YS, Seo JH. Strain engineering of Saccharomyces cerevisiae for enhanced xylose metabolism. Biotechnol Adv. 2013;31:851-61.

11. Lu C, Jeffries T. Shuffling of promoters for multiple genes to optimize xylose fermentation in an engineered Saccharomyces cerevisiae strain. Appl Environ Microbiol. 2007;73:6072-7.

12. Liu E, Hu Y. Construction of a xylose-fermenting Saccharomyces cerevisiae strain by combined approaches of genetic engineering, chemical mutagenesis and evolutionary adaptation. Biochem Eng J. 2011:48:204-10.

13. Peng B, Shen Y, Li X, Chen X, Hou J, Bao X. Improvement of xylose fermentation in respiratory-deficient xylose-fermenting Saccharomyces cerevisiae. Metab Eng. 2012;14:9-18.

14. Singh A, Pant D, Korres NE, Nizami AS, Prasad S, Murphy JD. Key issues in life cycle assessment of ethanol production from lignocellulosic biomass: challenges and perspectives. Bioresour Technol. 2010;101:5003-12.

15. Cheng KK, Zhang JA, Chavez E, Li JP. Integrated production of xylitol and ethanol using corncob. Appl Microbiol Biotechnol. 2010;87:411-7.

16. Yu X, Zheng Y, Dorgan KM, Chen S. Oil production by oleaginous yeasts using the hydrolysate from pretreatment of wheat straw with dilute sulfuric acid. Bioresour Technol. 2011;102:6134-40.

17. Barnett JA. The utilization of sugars by yeasts. Adv Carbohydr Chem Biochem. 1976:32:126-8.

18. Wang Y, Wang M, Cai D, Wang B, Wang Z, Qin P, Tan T. Efficient L-lactic acid production from sweet sorghum bagasse by open simultaneous saccharification and fermentation. RSC Adv. 2016;6:35771-7.

19. Alzate CAC, Toro OJS. Energy consumption analysis of integrated flowsheets for production of fuel ethanol from lignocellulosic biomass. Energy. 2006;31:2447-59.

20. Cheng J, Xie B, Zhou J, Song W, Cen K. Cogeneration of $\mathrm{H}_{2}$ and $\mathrm{CH}_{4}$ from water hyacinth by two-step anaerobic fermentation. Int $\mathrm{J}$ Hydrogen Energy. 2010;35:3029-35.

21. Song W, Cheng J, Zhou J, Xie B, Su H, Cen K. Cogeneration of hydrogen and methane from protein-mixed food waste by two-phase anaerobic process. Int J Hydrogen Energy. 2010;35:3141-6.

22. Cheng J, Lin R, Ding L, Song W, Li Y, Zhou J, Cen K. Fermentative hydrogen and methane cogeneration from cassava residues: effect of pretreatment on structural characterization and fermentation performance. Bioresour Technol. 2015;179:407-13.

23. Karhumaa K, Fromanger R, Hahn-Hägerdal B, Gorwa-Grauslund MF. High activity of xylose reductase and xylitol dehydrogenase improves xylose fermentation by recombinant Saccharomyces cerevisiae. Appl Microbiol Biot. 2007;73:1039-46.

24. Lin Y, Tanaka S. Ethanol fermentation from biomass resources: current state and prospects. Appl Microbiol Biotechnol. 2006;69:627-42.

25. Laopaiboon L, Nuanpeng S, Srinophakun P, Klanrit P, Laopaiboon P. Ethanol production from sweet sorghum juice using very high gravity technology: effects of carbon and nitrogen supplementations. Bioresour Technol. 2009;100:4176-82.
26. Srichuwong S, Fujiwara M, Wang X, Seyama T, Shiroma R, Arakane M, Mukojima N, Tokuyasu K. Simultaneous saccharification and fermentation (SSF) of very high gravity (VHG) potato mash for the production of ethanol. Biomass Bioenergy. 2009;33:890-8.

27. Michelson T, Kask K, Jõgi E, Talpsep E, Suitso I, Nurk A. L(+)-Lactic acid producer Bacillus coagulans SIM-7 DSM 14043 and its comparison with Lactobacillus delbrueckii ssp. lactis DSM 20073. Enzyme Microb Tech. 2006;39:861-7.

28. Taylor F, Marquez MA, Johnston DB, Goldberg NM, Hicks KB. Continuous high-solids corn liquefaction and fermentation with stripping of ethanol. Bioresour Technol. 2010;101:4403-8.

29. Xue C, Zhao J, Lu C, Yang S, Bai F, Tang IC. High-titer n-butanol production by Clostridium acetobutylicum JB200 in fed-batch fermentation with intermittent gas stripping. Biotechnol Bioeng. 2012;109:2746-56.

30. Silveira MG, Baumgärtner M, Rombouts FM, Abee T. Effect of adaptation to ethanol on cytoplasmic and membrane protein profiles of Oenococcus oeni. Appl Environ Microbiol. 2004;70:2748-55.

31. Lonvaud-Funel A. Lactic acid bacteria in the quality improvement and depreciation of wine. Antonie Van Leeuwenhoek. 1999;76:317-31.

32. Alexandre $H$, Guilloux-Benatier M. Yeast autolysis in sparkling wine-a review. Aust J Grape Wine R. 2006;12:119-27.

33. Coelho LF, de Lima CJB, Bernardo MP, Contiero J. D (-)-lactic acid production by Leuconostoc mesenteroides B512 using different carbon and nitrogen sources. Appl Biochem Biotechnol. 2011;164:1160-71.

34. Bustos G, Moldes AB, Cruz JM, Domínguez JM. Formulation of low-cost fermentative media for lactic acid production with Lactobacillus rhamnosus using vinification lees as nutrients. J Agric Food Chem. 2004;52:801-8.

35. de Lima CJB, Coelho LF, Blanco KC, Contiero J. Response surface optimization of D(-)-lactic acid production by Lactobacillus SMI8 using corn steep liquor and yeast autolysate as an alternative nitrogen source. Afr J Biotechnol. 2009:8:5842-6.

36. Wang $Y$, Yang $Z$, Qin $P$, Tan T. Fermentative L-(+)-lactic acid production from defatted rice bran. RSC Adv. 2014;4:8907-13.

37. Wang Y, Meng H, Cai D, Wang B, Qin P, Wang Z, Tan T. Improvement of L-lactic acid productivity from sweet sorghum juice by repeated batch fermentation coupled with membrane separation. Bioresour Technol. 2016;211:291-7.

38. Ma K, Maeda T, You H, Shirai Y. Open fermentative production of L-lactic acid with high optical purity by thermophilic Bacillus coagulans using excess sludge as nutrient. Bioresour Technol. 2014;151:28-35.

39. Zhang J, Ma X, Yu J, Zhang X, Tan T. The effects of four different pretreatments on enzymatic hydrolysis of sweet sorghum bagasse. Bioresour Technol. 2011;102:4585-9.

40. Cai D, Chang Z, Wang C, Ren W, Wang Z, Qin P, Tan T. Impact of sweet sorghum cuticular waxes (SSCW) on acetone-butanol-ethanol fermentation using Clostridium acetobutylicum ABE 1201. Bioresour Technol. 2013;149:470-3.

41. Sindhu R, Kuttiraja M, Binod P, Sukumaran RK, Pandey A. Physicochemical characterization of alkali pretreated sugarcane tops and optimization of enzymatic saccharification using response surface methodology. Renew Energy. 2014;62:362-8.

\footnotetext{
Ready to submit your research? Choose BMC and benefit from:

- fast, convenient online submission

- thorough peer review by experienced researchers in your field

- rapid publication on acceptance

- support for research data, including large and complex data types

- gold Open Access which fosters wider collaboration and increased citations

- maximum visibility for your research: over $100 \mathrm{M}$ website views per year
}

At $\mathrm{BMC}$, research is always in progress.

Learn more biomedcentral.com/submissions 